\title{
Non-invasive detection of bladder cancer by identification of abnormal CD44 proteins in exfoliated cancer cells in urine
}

\author{
M Sugiyama, A Woodman, T Sugino, S Crowley, K Ho, J Smith, Y Matsumura, \\ D Tarin
}

\begin{abstract}
Aims-To investigate the expression of CD44 proteins in exfoliated urothelial cells and in tumour tissues from bladder cancer patients. A further objective was to evaluate the diagnostic potential of the changes observed in the expression of these proteins as a marker for non-invasive detection of bladder cancer.

Methods-Naturally voided urine specimens were collected from 47 patients with bladder cancer or severe urothelial dysplasia $(n=3)$ and from a control group of 43 people with no evidence of neoplastic disease. Exfoliated urothelial cells floating in the urine were pelleted by centrifugation and lysed, and their constituent proteins extracted. The pattern of expression of CD44 proteins in each sample was examined by western blot analysis using a monoclonal antibody, Hermes 3 , which recognises an epitope on the polypeptide backbone of the CD44 protein. Immunohistochemical studies were performed on neoplastic $(n=10)$ and normal $(n=4)$ bladder tissue specimens which were snap frozen in liquid nitrogen before examination with antibodies to CD44 gene products (CD44s and CD44v6).
\end{abstract}

Results-Western blot analysis revealed several high molecular weight CD44 isoforms $>160 \mathrm{kDa}$ in urine cell lysates from $75 \%$ of patients with histologically confirmed bladder cancer and in two of the three patients with severe dysplasia. Such patterns were not detected in the urine cell pellets from any persons in the control group. Immunohistochemical studies of the tissue distribution of CD44s and CD44v6 showed that the differentiation and maturation of the epithelial cells in the normal bladder mucosa is accompanied by a decrease in CD44 protein expression. However, carcinoma cells overexpress standard and variant CD44 isoforms and continue to do so as they proceed through the thickened epithelial layer to the luminal surface and after they are shed into the urine.

Conclusions-The abnormal expression of CD44 proteins in exfoliated cancer cells may be a useful marker for the noninvasive diagnosis of bladder cancer. (f Clin Pathol: Mol Pathol 1995;48:M142-M147)

Keywords: Bladder cancer, exfoliated cancer cells, CD44 protein.
CD44, a widely distributed cell surface glycoprotein regarded as an extracellular adhesion molecule, is generated as various isoforms by alternative splicing of the products of at least 10 variant exons $(\mathrm{CD} 44 \mathrm{v})$ into a $37 \mathrm{kDa}$ polypeptide backbone encoded by nine other, constitutively expressed, exons (CD44s) ${ }^{1-3}$ The dominant isoform expressed in most normal cell types is the $90 \mathrm{kDa}$ "standard form" produced by heavy glycosylation of the basic backbone, but differing quantities of the individual variant isoforms, which are much larger, can also be detected in several normal tissues and organs. ${ }^{45}$ The types of variants produced differ according to the site of origin of the tissue.

We and other groups have reported marked changes in CD44 gene splicing patterns in various types of human cancer. ${ }^{6-11}$ These consist of a general increase in CD44 mRNA transcription with a progressive and disproportionate increase in variety and quantity of $\mathrm{CD} 44 \mathrm{v}$ isoforms as malignancy advances. Immunohistochemical analysis has indicated that there is also a good correlation between the altered quantity and distribution of CD44 variant forms (CD44v), particularly CD44v6, and tumour progression. ${ }^{10}$ These observations suggest the possibility that evaluation of CD44 gene activity could be useful in tumour diagnosis and evaluation of prognosis.

Early detection of neoplasia is an important objective because many cancers can be cured by surgical resection if diagnosed at an early stage. Bladder cancer is a common form of malignancy in which early diagnosis of primary tumours is difficult because of their inaccesibility. As the lesions have a strong tendency to recur, monitoring asymptomatic patients for recurrence is also problematic. Currently, urography and cystoscopy are the main methods for investigating symptomatic disease. However, because they are uncomfortable and labour intensive procedures, they are not optimal for routine monitoring of asymptomatic individuals who may be at risk of primary or recurrent tumours, or for general screening. Urinary cytology is simple and non-invasive but has insufficient sensitivity for routine general use, although it has a place for monitoring high risk populations in certain occupational groups. It is also expensive and labour intensive and a realistic alternative would be welcome. Consequently, there is an urgent need for a sensitive, reliable, and non-invasive method of detection of this disease. 
In a study which is relevant to this clinical requirement, we recently reported abnormal transcription of the CD44 gene in exfoliated cancer cells in urine specimens. ${ }^{11}$ However, as mRNA is unstable and the technology for its analysis is specialised, routine tests based upon this analyte are not yet widely available. An assay based upon detection of CD44 protein may circumvent these problems. This led us to investigate, by western blotting, whether there were any specific abnormalities in CD44 protein profile of desquamated urothelial cells from bladder cancer patients which could be a useful marker for early diagnosis. We now present the results of a study of urine specimens from 44 bladder cancer patients, three patients with severe urothelial dysplasia, and 43 people without malignancy. In this report the data from western blotting procedures are compared with the results obtained with immunohistochemical techniques on the quantity and distribution of CD44s and CD44v6 isoforms in normal and cancerous bladder tissue biopsies. We chose to study the status of expression of exon v6 (exon 11) in these tumour samples because previous studies, cited above, had indicated that increased expression of this transcript/epitope correlates with tumour progression.

The results indicate that it should be possible to design an accurate test for bladder cancer based upon abnormal CD44 gene expression.

\section{Methods \\ PREPARATION OF URINE CELL LYSATES}

Naturally voided urine specimens of about $50 \mathrm{ml}$ volume were collected from 47 patients with bladder cancer or severe urothelial dysplasia ( 37 male; 10 female) and 43 persons with no evidence of malignant disease ( 28 male; 15 female). The urine was collected into vessels containing $0.02 \mathrm{mM}$ amidinophenylmethane sulphonyl fluoride (APMSF) (Sigma) and $1 \mathrm{mM}$ EDTA

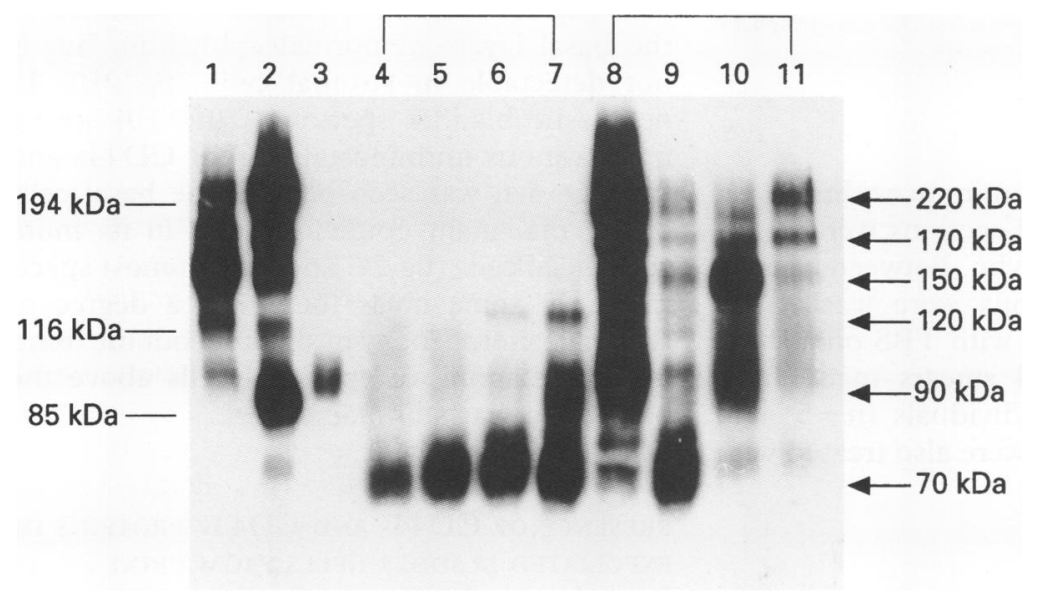

Figure 1 Western blot analysis of cell lysates with Hermes 3 (CD44s). Arrows show dominant CD44 proteins. Lanes 1, 2, and 3 show results with cell lysates from HT29 colon cancer cell line ( $0.5 \mu \mathrm{g} / \mathrm{lane}), \mathrm{RT112}$ bladder cancer cell line (0.5 $\mu \mathrm{g} / \mathrm{lane})$, and normal human leucocytes (1 $\mu \mathrm{g} / \mathrm{lane})$, respectively. Major protein bands of $\sim 150 \mathrm{kDa}$, $\sim 220 \mathrm{kDa}$ (plus $\sim 85 \mathrm{kDa}$ ), and $\sim 90 \mathrm{kDa}$ are seen in HT29, RT112, and leucocytes, respectively. The $90 \mathrm{kDa}$ band corresponds to CD44s, the $150 \mathrm{kDa}$ band to the epithelial form of CD44, and the $220 \mathrm{kDa}$ band to the largest variant form. The urine specimens from normal subjects (lanes 4-7) contain one to three band(s) of $M W \sim 70 \mathrm{kDa}$ to $\sim 120 \mathrm{kDa}$, whereas several bands of $\sim 70 \mathrm{kDa}$ to $\sim 220 \mathrm{kDa}$ are seen in specimens from cancer patients (lanes 8-11). Total protein loaded in each lane $=5 \mu \mathrm{g}$.
(Sigma), as protease inhibitors, and kept on ice during transport to the laboratory.

The cell pellets collected by centrifugation at $3000 \mathrm{rpm}$ for $15 \mathrm{~min}$ were lysed with $1: 1$ (wt/vol) of lysis buffer ( $20 \mathrm{mM}$ tris [pH 8.0], $150 \mathrm{mM} \mathrm{NaCl}, 20 \mathrm{mM}$ CHAPS, 2 mM EDTA, $0.04 \mathrm{mM}$ APMSF, $20 \mu \mathrm{g} / \mathrm{ml}$ aprotinin) on ice for 15 minutes. This lysate was clarified by centrifugation (12 $000 \mathrm{rpm}, 15 \mathrm{~min})$. The concentration of protein was determined (Bio-Rad protein assay kit) and adjusted to $5 \mu \mathrm{g} /$ lane by dilution with phosphate buffered saline containing $0.02 \mathrm{mM}$ APMSF and $1 \mathrm{mM}$ EDTA. Where necessary, samples were concentrated using a Microcon 30 membrane (Amicon).

Urine cell smears were prepared by washing the samples ( $3000 \mathrm{rpm}$ ) with Hank's buffered salt solution (HBSS), and spotting the cells onto poly $l$-lysine coated slides before fixing air dried preparations in $100 \%$ methanol at $4^{\circ} \mathrm{C}$. All smears were stored at $-20^{\circ} \mathrm{C}$ until required.

\section{WESTERN BLOT ANALYSIS}

Samples were boiled with gel loading buffer and subjected to $6 \%$ SDS-PAGE under reducing conditions. The separated proteins were electroblotted (100 mA, one hour) onto immobilon-P membranes (Millipore) using transfer buffer $(48 \mathrm{mM}$ tris, $39 \mathrm{mM}$ glycine, $0 \cdot 1 \%$ SDS, $20 \%$ methanol, $\mathrm{pH} 9 \cdot 2$ ). Nonspecific reactions were blocked with Tris buffered saline (TBS) containing 5\% skimmed milk before the membrane was incubated with monoclonal antibody Hermes 3 (anti-CD44s; epitope encoded by exon 5) at $4^{\circ} \mathrm{C}$ overnight, and then with peroxidase conjugated antimouse IgG (Sigma; 1/1000 dilution) for one hour at room temperature. All antibodies were diluted in 5\% skimmed milk in TBS and after each incubation the membrane was washed with TBS containing $0 \cdot 1 \%$ Tween 20 . Signals were detected by enhanced chemiluminescence with an ECL detection kit (Amersham).

\section{IMMUNOHISTOCHEMISTRY}

Cystoscopic biopsies and/or surgical resection specimens of bladder carcinoma to be used for immunohistochemistry $(n=10)$ were snap frozen in liquid nitrogen. Samples of non-neoplastic urothelial mucosa $(n=4)$ were obtained from ureters attached to nephrectomy specimens, from a cadaveric bladder specimen, and from a bladder biopsy for a non-malignant condition. Frozen sections $(5 \mu \mathrm{m})$ were fixed in cold methanol and preincubated with $20 \%$ normal rabbit serum in TBS at $37^{\circ} \mathrm{C}$ for 45 minutes before incubation with the primary monoclonal antibodies Hermes 3 (CD44s) or 2F10 (CD44v6) ( $R$ and D Systems) at $4^{\circ} \mathrm{C}$ overnight and at $37^{\circ} \mathrm{C}$ for 30 minutes next morning. Endogenous peroxidase activity was blocked with $0.3 \% \mathrm{H}_{2} \mathrm{O}_{2}$ in methanol for 10 minutes before addition of biotinylated antimouse IgG (Dako; 1/400 dilution; room temperature, two hours), followed by horseradish peroxidase conjugated ABComplex (Dako; room temperature, one hour). Immunostaining 
Results of western blot analysis in urine samples from bladder cancer patients and normal volunteers. As discussed in the text, samples which showed several bands of over $160 \mathrm{kDa}$ were judged to be positive and those with band $(s) \leqslant 120 \mathrm{kDa}$ negative in western blotting using monoclonal antibody Hermes-3 to CD44s

\begin{tabular}{|c|c|c|c|}
\hline Patient No & $\begin{array}{l}\text { Sex and } \\
\text { age (years) }\end{array}$ & $\begin{array}{l}\text { Histological stage } \\
\text { and grade of tumours }\end{array}$ & $\begin{array}{l}\text { Results in } \\
\text { western blot }\end{array}$ \\
\hline 1 & M29 & pT4G3L0 & + \\
\hline 2 & M52 & pTaG1 & + \\
\hline 3 & M72 & pTaG1 & - \\
\hline 4 & F70 & pT1G1L0 & - \\
\hline 5 & F63 & pT1G1L0 & + \\
\hline 6 & F85 & Severe dysplasia & + \\
\hline 7 & M60 & pT1G3L0 & + \\
\hline 8 & F79 & pT2G3 & - \\
\hline 9 & M54 & pT1G2L0 & + \\
\hline 10 & M81 & pT1G2LO & + \\
\hline 11 & M76 & pT1G2 & + \\
\hline 12 & M78 & pT2G2L0 & + \\
\hline 13 & F73 & pT1G2L0 & - \\
\hline 14 & M57 & pT1G1L0 & + \\
\hline 15 & F79 & pTIG1L0 & + \\
\hline 16 & F51 & pT1G1L0 & - \\
\hline 17 & M73 & pT2G3L0 & + \\
\hline 18 & M74 & pT1G1L0 & + \\
\hline 19 & M82 & pTaG1L0 & + \\
\hline 20 & M68 & pTaG1LO & - \\
\hline 21 & M81 & Cancer, NS & - \\
\hline 22 & M76 & pT1G3LO & + \\
\hline 23 & M84 & pT1G1L0 & - \\
\hline 24 & M80 & pT2G3L0 & + \\
\hline 25 & M68 & pT1G2L0 & + \\
\hline 26 & M72 & pT1G2L0 & + \\
\hline 27 & M70 & No tumour & - \\
\hline 28 & M46 & pT1G2L0 & + \\
\hline 29 & M73 & pT2G2L0 & + \\
\hline 30 & M76 & pT1G2L0 & - \\
\hline 31 & M75 & pT1G1L0 & + \\
\hline 32 & F73 & pT1G2L0 & + \\
\hline 33 & M69 & Severe dysplasia & + \\
\hline 34 & M83 & pT1G1L0 & + \\
\hline 35 & M56 & pT2G1L0 & - \\
\hline 36 & F82 & Severe dysplasia & - \\
\hline 37 & M78 & pT1G1L0 & + \\
\hline 38 & M72 & NS & - \\
\hline 39 & M70 & pT2G3L0 & + \\
\hline 40 & M56 & pT1G2L0 & + \\
\hline 41 & M71 & pT1G2L0 & + \\
\hline 42 & F54 & pTIG1L0 & + \\
\hline 43 & M64 & pT1G1L0 & + \\
\hline 44 & F74 & No tumour & - \\
\hline 45 & M54 & pTaG1L0 & + \\
\hline 46 & M48 & pT1G2L0 & + \\
\hline 47 & M88 & pT1G2L0 & + \\
\hline 48 & M83 & pTaG2L0 & + \\
\hline 49 & M78 & pT1G2L0 & + \\
\hline $\begin{array}{l}\text { Cancer patient total } \\
\text { Severe dysplasia }\end{array}$ & $\begin{array}{l}44 \\
3\end{array}$ & \multicolumn{2}{|c|}{ Numbers positive - $33(75 \%)$} \\
\hline $\begin{array}{l}\text { Normal volunteer total } \\
\text { Non-neoplastic at } \\
\text { cystoscopy }\end{array}$ & \multicolumn{2}{|c|}{$\begin{array}{l}41(\mathrm{M} 18-62, \mathrm{~F} 19-52) \\
2(\mathrm{M} 70, \mathrm{~F} 74)\end{array}$} & Numbers positive $-0(0 \%)$ \\
\hline
\end{tabular}

aTumour stage and grade were evaluated according to classification of International Union against Cancer (IUCC): p Ta = papillary non-invasive cancer; pT1 = tumour not extending beyond the lamina propria; pT2 = tumour invading superficial smooth muscle; $\mathrm{pT} 3=$ tumour invading deep muscle; pT4 = tumour invading surrounding pelvic tissue; $\mathrm{Gl}=$ high degree of differentiation; $\mathrm{G} 2=$ medium degree of differentiation; $\mathrm{G} 3$ = low degree of differentiation; $\mathrm{L} 0=$ no lymphatic invasion; NS $=$ not pathologically staged; + , positive case; - , negative case. was visualised using diaminobenzidine $/ \mathrm{H}_{2} \mathrm{O}_{2}$ (Sigma) as substrate and sections were counterstained with haematoxylin. Between all antibody incubations, sections were washed by $3 \times 5$ minute incubations with TBS on a shaking platform. Urine cell smears made from cell pellets of normal individuals $(n=5)$ and tumour bearers $(n=15)$ were also treated with the above protocol.

\section{Results}

ANALYSIS OF URINE CELL SEDIMENTS USING WESTERN BLOTTING

Western blot analysis of exfoliated urine cell lysates from patients with bladder cancer $(\mathrm{n}=$ 44) using monoclonal antibody Hermes 3 (CD44s) showed several high intensity bands with molecular weights ranging from $\sim 70 \mathrm{kDa}$ to $\sim 220 \mathrm{kDa}$ (fig 1). However, in lysates from the control group $(n=43)$, bands were only detected in the $\sim 70 \mathrm{kDa}$ to $90 \mathrm{kDa}$ range with a few further minor components up to $120 \mathrm{kDa}$. Under the same assay conditions two human tumour cell lines (namely HT29, which is derived from a colonic carcinoma, and RT112, derived from a bladder carcinoma) also displayed a range of high molecular weight isoforms of CD44, well above the size of those seen in normal urine cells or in blood leucocytes.

On the basis of all of the above information, the presence of bands above $160 \mathrm{kDa}$ was, for the further analysis of the data, defined as a positive criterion of malignancy. The table shows that samples from 33 of 44 patients (sensitivity $=75 \%$ ) with histologically proven bladder cancer showed this positive pattern, whereas samples from all 41 asymptomatic volunteers and from two cystocopically negative patients with non-neoplastic disease showed the negative pattern, consisting of one to three bands smaller than $\sim 120 \mathrm{kDa}$. There were no false positives in this control group (specificity $=100 \%$ )

Among the test group of patients with proven malignancy or severe dysplasia, there were six with very early ( $\mathrm{pTaG} 1$ ) tumours and four of these showed the positive high molecular weight pattern defined as positive. Of the three patients with severe urothelial dysplasia, two showed the positive western blotting pattern.

LOCALISATION OF CD44s AND CD44v6 IN NORMAL AND MALIGNANT BLADDER TISSUES Immunohistochemical studies with monoclonal antibodies to the standard form of CD44 (Hermes 3) and to CD44v6 (2F10) showed differences in the location of the corresponding CD44 epitopes between normal and neoplastic bladder mucosa. Hermes 3 showed that in normal bladder epithelium $(n=4)$ CD 44s protein can be detected only in the basal layers, and is also present in stromal cells, lymphocytes, vascular endothelial cells, and smooth muscle cells (fig 2A). CD44v6 is likewise confined to the basal layers of normal epithelium but is not detectable in stromal cells (fig 2B). In neoplastic bladder specimens $(n=10)$ strong membranous immunostaining for CD44s and for CD44v6 was seen both in the basal cells of the malignant epithelium and in its more superficial cells (fig $2 \mathrm{C}$ and $2 \mathrm{D}$ ) in most specimens. In some areas there was a degree of regional heterogeneity in staining, but the trend towards staining of epithelial cells above the basal layer was still maintained.

PRESENCE OF CD44s AND CD44V PROTEINS IN EXFOLIATED BLADDER CELLS FROM URINE Immunocytochemistry of urine cell smears showed that some cancer cells in urine from cancer patients stained positively for CD44v6 (fig 3A). This confirmed that some of the $\mathrm{CD} 44 \mathrm{v}$ protein is retained even following exfoliation, but that the tumour cells show heterogeneous expression. Inflammatory cells were negative. As expected, normal and neoplastic epithelium and inflammatory cells in 

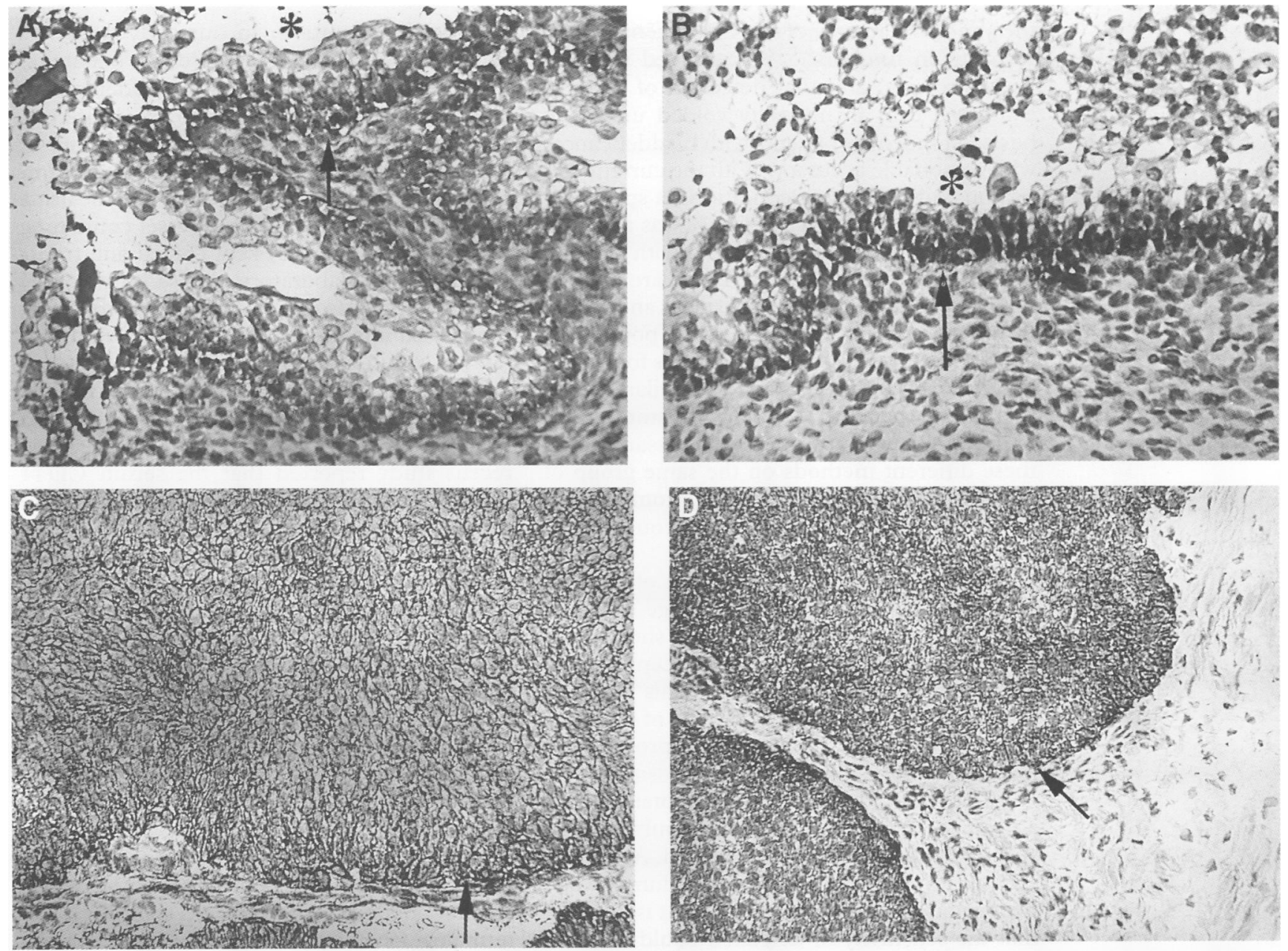

Figure 2 Immunohistochemical localisation of CD44 proteins in normal and neoplastic bladder tissues. The cell membranes of basal epithelial cells of normal bladder are moderately stained with monoclonal antibody $(\mathrm{mAb})$ Hermes 3 to CD44s $(A)$ and with mAb $2 F 10$ to CD44v6 (B), whereas superficial epithelial cells are negative. Underlying stromal cells only react with Hermes 3 and do not contain detectable quantities of v6. In bladder carcinoma, both superficial and basal epithelial cells stain strongly with Hermes $3(C)$ and with $2 F 10$ to CD44v6 (D). (Magnification $\times 560$.) Arrows define the position of the epithelial-stromal boundary and asterisks are positioned over the luminal surface of the epithelium.
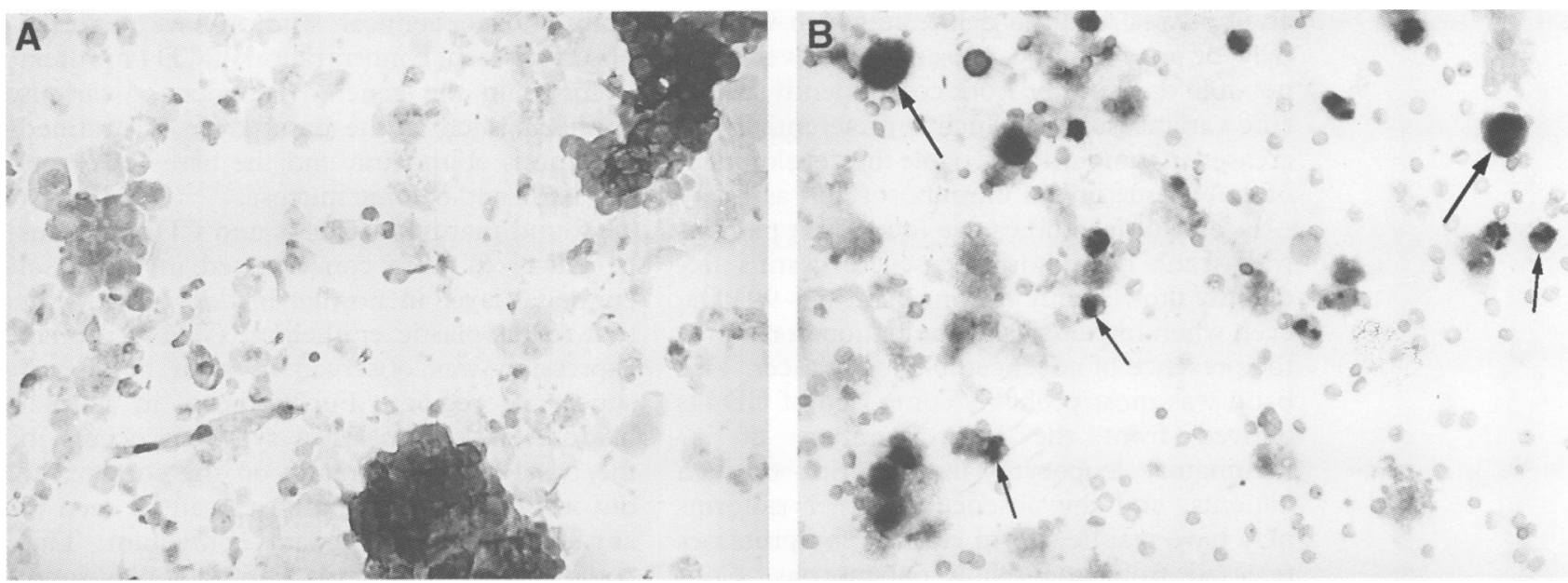

Figure 3 Immunohistochemical studies on CD44 protein expression in cells pelleted from the urine of bladder cancer patients. (A) Some exfoliated carcinoma cells in urine from a bladder cancer patient retain immunostaining for CD44v6 (2F10) but others are negative. Inflammatory cells do not show immunoreactivity for this epitope. (B) Exfoliated cancer cells (large arrows) as well as inflammatory cells (small arrows), including polymorphs, stain for CD44s with Hermes 3. (Magnification $\times 554$.)

the urine all stained for CD44s with Hermes 3 (fig 3B). Normal urine smears showed no staining with monoclonal antibody $2 \mathrm{~F} 10$ for CD44v6 (data not shown). All of these data are in accordance with the immunohistochemical results on tissue sections and with the western blotting findings.

\section{Discussion}

We have previously reported that CD44 mRNA is detectable in exfoliated urine cells ${ }^{11}$ and we have now shown that CD44 protein is also detectable in these cells, using western blotting and immunohistochemistry. The present work has further demonstrated that at least some of 
the abnormal activity of the CD44 gene known to occur in tumours ${ }^{6-11}$ is translated into unusual proteins, and that detection of these in exfoliated cells in naturally voided urine can be used to identify patients with bladder cancer with reasonable accuracy. With the current collection and processing conditions, a specificity of $100 \%$ and a sensitivity of $75 \%$ was achieved for the identification of patients with bladder cancer by western blotting. These are average figures for the overall range of stages and grades of bladder cancer among this test population and are better than published figures for cancer detection by urine cytology in similar pooled groups of patients. ${ }^{1314}$ For accurate comparison, however, it would be necessary to use these different methods on the same group of patients. It also seems likely that a combination of the two methods of analysis could prove powerful in appropriate cases.

It is interesting to note that $66 \%$ of samples from patients with very early stage tumours (pTaG1) and severe dysplasia also showed the abnormal CD44 protein pattern seen in more advanced bladder malignancy. This suggests that the disturbances in the activity of this gene begin very early in the neoplastic process and may prove to be clinically useful.

Additionally, these results were obtained with a protocol involving collection of only a single specimen of urine from each person. As factors such as urine retention times and diurnal variations may influence these results, it is possible that the sensitivity of detection could increase with examination of repeat specimens. The criterion used for assigning western blotting results to cancer or non-neoplastic categories was the presence or absence of high molecular weight CD44 isoforms detectable by antiCD44 monoclonal antibody Hermes 3, and no attempt was made to delineate which variants may or may not be present. However, it is possible that further work could identify a specific variant isoform which is preferentially increased in tumours and enable the development of an enzyme linked immunosorbent assay.

In our initial studies, we found that patients with frank haematuria or severe cystitis frequently showed only a strong band at $\sim 90 \mathrm{kDa}$, even when histological examination confirmed the presence of advanced bladder cancer. This band was most probably composed of CD44s derived from the large numbers of inflammatory leucocytes in the urine of such patients, and the absence of larger isoforms may have resulted from cleavage by proteases released from the dying polymorphs. Consequently, patients with cystitis or those with obvious signs of haematuria were excluded from the study. This technical issue does not diminish the potential value of large CD44 proteins as diagnostic markers for early detection of bladder neoplasia: patients with pyuria could first be treated to eradicate infection and then tested if symptoms persist, and ones with persistent haematuria should, in any case, be cystoscoped.

It should be noted that in our experience the immediate collection of the voided urine into a vessel containing powerful protease inhibitors is critically important. In our early work, we sometimes obtained negative results in batches of samples from patients with bladder cancer which were delayed in transit to the laboratory. Careful analysis showed that the conditions of specimen collection and transport are important. For best results we found that the urine should be: (1) collected in a vessel containing protease inhibitors; (2) kept chilled and transported to the laboratory the same day; (3) centrifuged and frozen $\left(-70^{\circ} \mathrm{C}\right)$ until analysed, if not used immediately; and (4) analysed preferably within one month.

The exact mechanisms responsible for the lability of the samples between collection and analysis is yet to be determined. However, a recent study reported that the serum CD44 concentration in patients with gastric and colon cancer correlated with tumour burden and that the level decreased after surgical resection of the tumour in colon cancer patients. ${ }^{15}$ The authors suggested three possibilities for the raised serum CD44 in these patients: active shedding of the CD44 molecule by tumour cells; its release from dying tumour cells; or release by proteolytic enzymatic mechanisms. In preliminary experiments with CD44 from exfoliated urinary cells we have confirmed that both CD44s and CD44v forms can be cleaved by proteolytic enzymes including plasmin, tissue kallikrein, and trypsin (data not shown).

Good correlation has been observed in our results obtained with western blotting, immunohistochemistry, and reverse transcriptasepolymerase chain reaction techniques on normal and neoplastic bladder tissue and exfoliated cells. Clearly, therefore, during the development of bladder cancer, severe derangements occur in the control of CD44 gene activity or in the processing of its products. Several immunohistochemical studies have reported observing focal concentration of CD44 protein isoforms in the generative region of various epithelia, such as the basal layer of stratified squamous epithelium and the bases of crypts in gastric and colonic mucosa. ${ }^{4581016}$ Similarly, we found that both CD44s and CD44 variant 6 (CD44v6) were concentrated in the basal epithelial layer in normal bladder tissue, but that in neoplastic epithelium CD44v protein expression was observed in both basal and superficial regions. Furthermore, in normal bladder epithelium DNA synthesis occurs in the basal layer and rarely on the surface, ${ }^{1718}$ but in bladder cancer mitoses can be seen in any part of the malignant epithelium. This could indicate that CD44 proteins play some role in cell turnover but could also simply reflect the need to generate more membrane proteins when the cells are rapidly dividing. However, the observed imbalance between CD44v and CD44s production in tumour tissue relative to corresponding normal tissue, ${ }^{6-11}$ and the recent demonstration of the retention of intronic sequences in immature mRNA transcripts in malignant cells, ${ }^{1920}$ indicates that the disturbances in regulation of CD44 turnover in malignancy are profound. At present, it is not possible to comment on whether these disturbances are directly concerned with the 
development and progression of the neoplasm or are a side effect. However, the increasing severity of the changes observed in advanced and metastatic malignancy may indicate that the disturbances have a causal role.

We thank J O'D McGee, $\mathrm{H}$ Bodenmuller, $M$ Kauffman, and $\mathrm{K}$ Yoshida for helpful discussions, J Cook and R Robinson for collection of urine samples, and L Summerville for invaluable help in preparing the manuscript. We also wish to acknowledge help in preparing the manuscript. We also wish to acknowledge
with gratitude the generous gift of mAb Hermes 3 by Dr E C with gratitude the generous gift of mAb Hermes 3 by Dr E C
Butcher. This work was supported by a research contract beButcher. This work was supported by a research contract be-
tween Boehringer Mannheim $\mathrm{GmbH}$ and Oxford University.

1 Screaton GR, Bell MV, Jackson DG, Cornelis FB, Gerth U, Bell JI. Genomic structure of DNA encoding the lymphocyte homing receptor CD44 reveals at least 12 alternatively spliced exons. Proc Natl Acad Sci USA 1992; 89:12160-4.

2 Tolg C, Hofmann M, Herrlich P, Ponta H. Splicing choice from ten variant exons establishes CD44 variability. Nucleic from ten variant exons esta

3 Screaton GR, Bell MV, Bell JI, Jackson DG. The identification of a new alternative exon with highly restricted tissue expression in transcripts encoding the mous Pgp-1 (CD44) homing receptor. F Biol Chem 1993;268: $12235-8$

4 Fox SB, Fawcett J, Jackson DG, Collins I, Gatter KC Harris AL, et al. Normal human tissues, in addition to some tumors, express multiple different CD44 isoforms. Cancer Res 1994;54:4539-46.

5 Mackay CR, Terpe H-J, Stauder R, Marston WL, Stark H, Gunthert U. Expression and modulation of CD44 variant isoforms in humans. $\mathcal{F}$ Cell Biol 1994;124:71-82.

6 Matsumura Y, Tarin D. Significance of CD44 gene products for cancer diagnosis and disease evaluation. Lancet 1992 for cancer diag:

7 Tanabe KK, Ellis LM, Saya H. Expression of CD44R1 adhesion molecule in colon carcinomas and metastases. Lancet 1993;341:725-6.

8 Heider K-H, Dammrich J, Skroch-Angel P, Muller-Hermelink H-K, Vollmers HP, Herrlich P, et al. Differential expression of CD44 splice variants in intestinal- and diffuse-type human gastric carcinomas and normal gastric mucosa. Cancer Res 1993;53:4197-203.

9 Dall P, Heider K-H, Hekele A, von Minchwitz G, Kaufmann $M$, Ponta $H$, et al. Surface protein expression and messenger RNA-splicing analysis of CD44 in uterine cervical cancer and normal cervical epithelium. Cancer Res 1994; 54:3337-41

10 Wielenga VJM, Heider K-H, Offerhaus GJA, Adolf GR, van den Berg FM, Ponta $\mathrm{H}$, et al. Expression of CD44 variant proteins in human colorectal cancer is related to tumor progression. Cancer Res 1993;53:4754-6.

11 Matsumura Y, Hanbury D, Smith J, Tarin D. Non-invasive detection of malignancy by identification of unusual CD44 gene activity in exfoliated cancer cells. BMF 1994;308: 619-24.

12 Mulder J-WR, Kruyt PM, Sewnath M, Oosting J, Seldenrijk $\mathrm{CA}$, Weidema WF, et al. Colorectal cancer prognosis and expression of exon-v6-containing CD44 proteins. Lancet expression of exon-

13 Matzkin H, Moinuddin SM, Soloway MS. Value of urine cytology versus bladder washing in bladder cancer. Urology 1992;39:201-3.

14 Koss LG, Deitch D, Tamamathan R, Sherman AB. Diagnostic value of cytology of voided urine. Acta Cytol 1985; 29:810-6.

15 Guo Y-J, Liu G, Wang X, Jin D, Wu M, Ma J, et al. Potential use of soluble CD44 in serum as indicator of tumor burden and metastasis in patients with gastric or colon cancer. Cancer Res 1994;54:422-6.

16 Abbasi AM, Chester KA, Talbot IC, Macpherson AS, Boxer $\mathrm{G}$, Forbes A, et al. CD44 is associated with proliferation in normal and neoplastic human colorectal epithelial cells. in normal and neoplastic human colorectal

17 Tsujihashi H, Matsuda H, Uejima S, Akiyama T, Kurita T Cell proliferation of human bladder tumors. F Urol 1989 142:1113-6.

18 Limas C, Bigler A, Bair R, Bernhart P, Reddy P. Proliferative activity of urothelial neoplasms: comparison of BrdU incorporation, Ki67 expression and nucleolar organiser regions. F Clin Pathol 1993;46:159-65.

19 Matsumura Y, Matsumura S, Smith J, Tarin D. Cancer specific novel abnormalities in splicing of CD44 gene products in bladder tumours. In: Proceedings of the Eighth products in bladder tumours. In: Proceedings of the Eighth Differentiation (ISD), 1994:199 (abstract P140).

20 Matsumura Y, Sugiyama M, Smith JC, Tarin D. Unusual retention of introns in CD44 gene transcripts in bladder cancer provides new diagnostic and clinical oncological opportunities. $\mathcal{F}$ Pathol (in press). 